\section{Screening Tomato Accessions for Resistance to Xanthomonas campestris pv. vesicatoria, Race T3}

\author{
J.W. Scott, J.B. Jones, and G.C. Somodi \\ Gulf Coast Research and Education Center, University of Florida, Institute of \\ Food and Agricultural Sciences, 5007 60th Street East, Bradenton, \\ FL 34203-9324

\section{R.E. Stall \\ Plant Pathology Department, University of Florida, Institute of Food and Agricultural Sciences, 2515 Fifield Hall, P.O. Box 110680, Gainesville, FL 32611-0680}

Additional index words. bacterial spot, disease resistance, hypersensitivity, Lycopersicon esculentum, plant breeding

\begin{abstract}
Tomato (Lycopersicon esculentum Mill.) accessions were tested for hypersensitivity and rated for resistance following field inoculation with tomato race 3 (T3) of the bacterial spot pathogen Xanthomonas campestris pv. vesicatoria (Doidge) Dye (Xcv) in 1992 and 1993. Hawaii 7981, PI 126932, PI 128216, and selections of the latter two expressed hypersensitivity. Hawaii 7981, only tested in the field in 1993, was nearly symptomless and developed significantly less disease than any other accession. PI 128216 had a level of disease similar to susceptible 'Solar Set' when tested in 1993. However, a selection from it (PI 126218-S) was significantly more resistant than 'Solar Set' in both years. Although PI 126932 had a level of disease similar to 'Solar Set' in both years, a selection from it (PI 126932-1-2) was significantly more resistant than 'Solar Set' in 1993. Other accessions without hypersensitive responses but more resistant than 'Solar Set' for two seasons were PI 114490, PI 126428, PI 340905-S, and PI 155372. Hawaii 7975 was significantly more resistant than 'Solar Set' in the one season it was tested.
\end{abstract}

Bacterial spot of tomato is a serious disease in Florida, causing yield and fruit grade losses by defoliation and fruit lesions (Cox, 1966; Pohronezny and Volin, 1983). Spray programs to prevent the disease are costly and generally are not effective under hot, rainy conditions that favor the disease (Conover and Gerhold, 1981; Nayudu and Walker, 1960). In a field experiment, Scott and Jones (1986) identified a high level of foliar, field resistance to Xanthomonas campestris pv. vesicatoria $(\mathrm{Xcv})$ race T1 in the breeding line Hawaii 7998. Later, Scott and Jones (1989) reported in a field study that this race $\mathrm{T} 1$ resistance was controlled quantitatively. Furthermore, Jones and Scott (1986) found Hawaii 7998 to express a hypersensitive reaction to race $\mathrm{T} 1$, which later was determined to be controlled by two or three genes (Wang et al., 1994; Whalen et al., 1993). There is still uncertainty about the role of hypersensitivity to race $\mathrm{T} 1$ and field resistance (Wang et al., 1994).

Received for publication 22 Aug. 1994. Accepted for publication 6 Mar. 1995. Florida Agricultural Experiment Station Journal series no. R-04050. This research was supported by the U.S. Dept. of Agriculture under Cooperative State Research Service Special Grant $92-34135-7283$ by the Caribbean Basin Advisory Group. The cost of publishing this paper was defrayed in part by the payment of page charges. Under postal regulations, this paper therefore must be hereby marked advertisement solely to indicate this fact.
Although development of commercially acceptable resistant germplasm has progressed over the last 10 years, it has been difficult to obtain highly resistant lines with a concentrated set of large fruit. To date, we have found no resistant cultivars available. Some of the difficulties of breeding for resistance to Xcv have been reported (Scott et al., 1989). In 1991, a new strain of Xcv was identified in Florida that differed from race $\mathrm{T} 1$ in its ability to hydrolyze starch. This strain does not cause a hypersensitive response on Hawaii 7998 and recently was designated race $\mathrm{T} 3$ (Jones et al., 1995). There is also evidence based on in vitro studies that T3 is antagonistic to race T1 (ElMorsy et al., 1994). During Summer 1992 and 1993, strains of T3 predominated in breeding plots even though plants had been inoculated with race $\mathrm{T} 1$. It became apparent that resistance to race $\mathrm{T} 3$ needed to be identified and then combined with race $\mathrm{T} 1$ resistance, for resistance breeding to be an effective strategy to manage Xcv in Florida. This paper reports on hypersensitivity tests and two seasons of field screening of accessions for race T3 resistance in tomato.

\section{Materials and Methods}

Season 1992. In previous work, more than 200 accessions reported to possess a tomato bacterial resistance were tested for $\mathrm{Xcv}$ race T1 (Scott and Jones, 1986). These 200 accessions were later tested for hypersensitivity (as measured by confluent necrosis) and/or small and few lesions to $\mathrm{Xcv}$ race $\mathrm{T} 2$ by Wang (1992). Sixteen plant introductions (PIs) were selected for their race $\mathrm{T} 2$ hypersensitivity or lesion expression. In 1991 and 1992, we screened these 16 PIs in greenhouses at Gainesville, Fla., for race T3 using the method of Wang (1992). Some of the accessions segregated for rapid confluent necrosis to race $\mathrm{T} 3$ and selections were made. The 1992 field experiment consisted of the 16 PIs (less PI 128216, which did not germinate); five selections (PI 79532-S, PI 128216-S, PI 155372-S, PI 340905-S, and PI 114490-S); and three controls. Controls were Hawaii 7998 (race T1 resistant), 'Campbell-28' (race T1 partially resistant), and 'Solar Set' (races T1 and T3 susceptible) (Table 1).

Seed were sown in the greenhouse in Black Beauty spent coal (Reed Minerals Div., Highland, Ind.) medium on 26 June and transplanted into Todd planter flats $\left(3.8-\mathrm{cm}^{3}\right.$ cell size) (Speedling, Sun City, Fla.) on 6 July. They were inoculated on 7 Aug. with $\mathrm{Xcv}$ race T3 by the spray-inoculation seedling screening technique as described by Somodi et al. (1994). Plants were transplanted to the field on 10 Aug. on 20-cm-high, 81-cm-wide beds of EauGallie fine sand that had been fumigated with $67 \%$ methyl bromide : $33 \%$ chloropicrin at $392 \mathrm{~kg} \cdot \mathrm{ha}^{-1}$ and covered with white polyethylene mulch 2 weeks before transplanting.

The entries were arranged in a randomized complete-block design with three blocks and five plants per plot. Plants were spaced $46 \mathrm{~cm}$ apart within plots that were $91 \mathrm{~cm}$ apart in rows, with $152 \mathrm{~cm}$ between rows. Recommended fertilizer and insecticide programs were followed, and the label rate of 2,4,5,6tetrachloroisophthalonitrile (chlorothalonil) was applied to control fungal pathogens. Plants were grown with stake culture and irrigated by seepage from ditches adjacent to the six experimental beds. On 15 Sept., each plot was evaluated for bacterial spot disease severity by rating the two aisle sides of the staked plants using the scale of Horsfall and Barratt (1945) and then averaging the two ratings per plot. The Horsfall-Barratt scale translates percentage of diseased tissue to numbers, where $1=$ $0 \%, 2=0 \%$ to $3 \%, 3=3 \%$ to $6 \%, 4=6 \%$ to $12 \%, 5=12 \%$ to $25 \%, 6=25 \%$ to $50 \%, 7=$ $50 \%$ to $75 \%, 8=75 \%$ to $87 \%, 9=87 \%$ to $94 \%$, $10=94 \%$ to $97 \%, 11=97 \%$ to $100 \%$, and 12 $=100 \%$ diseased tissue. Data were tested by analysis of variance, and significant differences among treatment means were determined using Duncan's multiple range test at $P$ $\leq 0.05$.

Season 1993. The same accessions tested in 1992 were retested in 1993, except for PI 128643, PI 79532, PI 155372, PI 340905, and PI 144490. Only selections of the latter four PIs were tested in 1993. There were also additional entries that included PI 128216, seven bacterial-wilt-tolerant (Pseudomonas solanacearum E.F. Smith) breeding lines from the Univ. of Hawaii, two selections (PI 1282161-2 and PI 126932-1-2), and three hybrids (Hawaii $7998 \times$ Walter, Hawaii 7998 x PI 126932, and PI 271385 x PI 126932) (Table 2). 
Seed were sown on 24 May and seedlings were transplanted to planter flats on 9 June. Plants were inoculated on 12 July and were transplanted to the field on 16 July. Bacterial

spot disease severity evaluations were made on 2 Sept. All other procedures and locations were as described in the 1992 experiment.

Hypersensitivity. On 13 Apr. 1994, seed of

Table 1. Hypersensitivity and disease severity for tomato accessions inoculated with Xanthomonas campestris pv. vesicatoria $(\mathrm{Xcv})$ race $\mathrm{T} 3$ in 1992.

\begin{tabular}{|c|c|c|c|}
\hline Accession $^{2}$ & Species & Hypersensitivity ${ }^{y}$ & $\begin{array}{c}\text { Disease } \\
\text { severity }^{\mathrm{x}}\end{array}$ \\
\hline PI 128643 & Lycopersicon peruvianum & - & $5.5 \mathrm{a}^{\mathrm{w}}$ \\
\hline PI 324707 & L. esculentum & - & $5.3 \mathrm{ab}$ \\
\hline PI 340905 & L. pimpinellifolium & - & $5.0 \mathrm{a}-\mathrm{c}$ \\
\hline PI 79532-S & L. pimpinellifolium & - & $4.7 \mathrm{a}-\mathrm{d}$ \\
\hline Solar Set & L. esculentum & - & $4.7 \mathrm{a}-\mathrm{d}$ \\
\hline PI 273445 & L. esculentum & - & $4.5 \mathrm{~b}-\mathrm{e}$ \\
\hline PI 127807 & L. esculentum & - & $4.5 \mathrm{~b}-\mathrm{e}$ \\
\hline PI 99782 & L. esculentum & - & $4.2 \mathrm{c}-\mathrm{e}$ \\
\hline PI 262173 & L. esculentum & - & $4.2 \mathrm{c}-\mathrm{e}$ \\
\hline PI 306216 & L. pimpinellifolium & - & $4.2 \mathrm{c}-\mathrm{e}$ \\
\hline PI 244672 & L. esculentum & - & $4.2 \mathrm{c}-\mathrm{e}$ \\
\hline PI 79532 & L. pimpinellifolium & - & $4.0 \mathrm{de}$ \\
\hline Hawaii 7998 & L. esculentum & - & $4.0 \mathrm{de}$ \\
\hline PI 126932 & L. pimpinellifolium & + & $4.0 \mathrm{de}$ \\
\hline PI 128216-S & L. pimpinellifolium & + & $3.7 \mathrm{e}-\mathrm{g}$ \\
\hline PI 155372 & L. esculentum & - & $3.7 \mathrm{e}-\mathrm{g}$ \\
\hline Campbell 28 & L. esculentum & - & $3.7 \mathrm{e}-\mathrm{g}$ \\
\hline PI 155372-S & L. esculentum & - & $3.7 \mathrm{e}-\mathrm{g}$ \\
\hline PI 126428 & L. esculentum & - & $3.0 \mathrm{f}-\mathrm{h}$ \\
\hline PI 114490 & L. esculentum & - & $3.0 \mathrm{f}-\mathrm{h}$ \\
\hline PI 271385 & L. esculentum & - & $2.8 \mathrm{gh}$ \\
\hline PI 340905-S & L. pimpinellifolium & - & $2.3 \mathrm{~h}$ \\
\hline PI 114490-S & L. esculentum & - & $2.3 \mathrm{~h}$ \\
\hline
\end{tabular}

${ }^{2} \mathrm{PI}$ numbers with $-\mathrm{S}$ were selections of that PI number for $\mathrm{Xcv}$ race T3 resistance.

${ }^{y}$ Based on confluent necrosis $24 \mathrm{~h}$ after injection of $10^{8}$ colony-forming units bacteria/ml; + indicates the presence of confluent necrosis (hypersensitivity), - indicates no necrosis.

${ }^{x}$ Horsfall-Barratt (1945) scale, higher numbers indicate greater disease.

"Mean separation by Duncan's multiple range test at $P \leq 0.05$.

Table 2. Hypersensitivity and disease severity for tomato accessions inoculated with Xanthomonas campestris pv. vesicatoria $(\mathrm{Xcv})$ race $\mathrm{T} 3$ in 1993.

\begin{tabular}{|c|c|c|c|}
\hline Accession $^{2}$ & Species & Hypersensitivity $^{y}$ & $\begin{array}{c}\text { Disease } \\
\text { severityx }\end{array}$ \\
\hline Hawaii 7997 & Lycopersicon esculentum & - & $5.0 \mathrm{a}^{\mathrm{w}}$ \\
\hline Solar Set & L. esculentum & - & $4.7 \mathrm{ab}$ \\
\hline PI 128216 & L. pimpinellifolium & + & $4.5 \mathrm{a}-\mathrm{c}$ \\
\hline Hawaii 7982 & L. esculentum & - & $4.5 \mathrm{a}-\mathrm{c}$ \\
\hline Hawaii 7976 & L. esculentum & - & $4.5 \mathrm{a}-\mathrm{c}$ \\
\hline PI 273445 & L. esculentum & - & $4.5 \mathrm{a}-\mathrm{c}$ \\
\hline Hawaii 7996 & L. esculentum & - & $4.5 \mathrm{a}-\mathrm{c}$ \\
\hline PI 79532-S & L. pimpinellifolium & - & $4.3 \mathrm{a}-\mathrm{d}$ \\
\hline PI 126932 & L. pimpinellifolium & + & $4.3 \mathrm{a}-\mathrm{d}$ \\
\hline Hawaii 7983 & L. esculentum & - & $4.3 \mathrm{a}-\mathrm{d}$ \\
\hline Campbell 28 & L. esculentum & - & $4.3 \mathrm{a}-\mathrm{d}$ \\
\hline PI 271385 & L. esculentum & - & $4.3 \mathrm{a}-\mathrm{d}$ \\
\hline PI 128216-1-2 & L. pimpinellifolium & + & $4.3 \mathrm{a}-\mathrm{d}$ \\
\hline PI 306216 & L. pimpinellifolium & - & $4.0 \mathrm{~b}-\mathrm{e}$ \\
\hline \multicolumn{4}{|l|}{ Hawaii $7998 x$} \\
\hline Walter & L. esculentum & - & $4.0 \mathrm{~b}-\mathrm{e}$ \\
\hline PI 262173 & L. esculentum & - & $3.8 \mathrm{c}-\mathrm{f}$ \\
\hline Hawaii 7975 & L. esculentum & - & $3.7 \mathrm{~d}-\mathrm{g}$ \\
\hline Hawaii 7998 & L. esculentum & - & $3.5 \mathrm{e}-\mathrm{h}$ \\
\hline PI 114490-S & L. esculentum & - & $3.5 \mathrm{e}-\mathrm{h}$ \\
\hline PI 126932-1-2 & L. pimpinellifolium & + & $3.3 \mathrm{e}-\mathrm{h}$ \\
\hline PI 126428 & L. esculentum & - & $3.3 \mathrm{e}-\mathrm{h}$ \\
\hline PI 340905-S & L. pimpinellifolium & - & $3.2 \mathrm{f}-\mathrm{h}$ \\
\hline PI 155372-S & L. esculentum & - & $3.0 \mathrm{gh}$ \\
\hline Hawaii $7998 x$ & L. esculentum $\mathrm{X}$ & & \\
\hline PI 126932 & L. pimpinellifolium & + & $2.8 \mathrm{hi}$ \\
\hline PI $271385 x$ & L. esculentum $\mathrm{x}$ & & \\
\hline PI 126932 & L. pimpinellifolium & + & $2.8 \mathrm{hi}$ \\
\hline PI 128216-S & L. pimpinellifolium & + & $2.2 \mathrm{i}$ \\
\hline Hawaii 7981 & L. esculentum & + & $1.3 \mathrm{j}$ \\
\hline
\end{tabular}

${ }^{2} \mathrm{PI}$ numbers with $-\mathrm{S},-\mathrm{S} 1$, or $-1-2$ were selections of that PI number for Xcv race T3 resistance.

${ }^{\mathrm{y}}$ Based on confluent necrosis $24 \mathrm{~h}$ after injection of $10^{8}$ colony-forming units bacteria/ml; + indicates the presence of confluent necrosis (hypersensitivity), - indicates no necrosis.

${ }^{x}$ Horsfall-Barratt (1945) scale, higher numbers indicate greater disease.

"Mean separation by Duncan's multiple range test at $P \leq 0.05$. accessions used in the 1992 and 1993 experiments were sown in wood flats containing spent coal described previously. On 25 Apr., seedlings were transplanted into $385-\mathrm{cm}^{3}$ pots and grown in a plastic greenhouse with open sides under ambient conditions $(\approx 30$ to $34 \mathrm{C}$ day/17 to $23 \mathrm{C}$ night). They were topped after reaching the four true-leaf stage on 13 or 16 May. The hypersensitive reaction was determined by using a syringe to infiltrate portions of a mature leaflet on each plant with $10^{8}$ colony-forming units $/ \mathrm{ml}$ of race $\mathrm{T} 3$ isolate XV 938. After infiltration on 17 or 19 May, plants were placed in a growth chamber maintained at $24 \mathrm{C}$ with a 12 -h photoperiod provided by cool-white fluorescent lights $(\approx 110$ $\left.\mu \mathrm{mol} \cdot \mathrm{m}^{-2} \cdot \mathrm{s}^{-1}\right)$. Plants were rated qualitatively for hypersensitive reaction as measured by confluent necrosis (complete tissue collapse in infiltrated area) $24 \mathrm{~h}$ after infiltration when some accessions showed necrosis and susceptible controls did not.

\section{Results and Discussion}

Plants of PI 126932, PI 128216, selections of these two PIs, and Hawaii 7981 produced a hypersensitive reaction when infiltrated with $\mathrm{Xcv}$ race T3, as did plants of the two hybrids with PI 126932 (Tables 1 and 2). Hawaii 7981 was not field-tested in 1992, but in 1993 it had almost no symptoms and was significantly more resistant than all other accessions (Table 2). Plants of PI 126932 were susceptible both seasons, but the selection PI 126932-1-2 was more resistant than PI 126932 and the susceptible control 'Solar Set' in 1993 (Tables 1 and 2). PI 128216-S was more resistant than 'Solar Set' both seasons. In 1993, PI 128216-S also was significantly more resistant than PI 128216 and PI 128216-1-2, whereas the latter two were similar to 'Solar Set'. The selection PI 340905-S was significantly more resistant than PI 340905 in 1992 (Table 1). Thus, PI 126932 , PI 128216, and PI 340905 segregated for resistance and the greenhouse selections had enhanced field resistance. Other selections, PI $114490-S$ and PI $155372-S$, were not significantly more resistant than their respective PIs in 1992 (Table 1). Thus, these two selections are considered to be synonymous with their respective PIs.

PIs, or selections of those PIs, without hypersensitive responses that were significantly more resistant than 'Solar Set' in both seasons were PI 114490, PI 126428, PI 340905-S, and PI 155372 (Tables 1 and 2). Hawaii 7975 was significantly more resistant than 'Solar Set' in the one season it was tested (1993). Accessions significantly more resistant than 'Solar Set' in one of two seasons were PI 271385 (1992), PI 262173 (1993), 'Campbell 28' (1992), and Hawaii 7998 (1993).

The role of the tomato hypersensitive response to $\mathrm{Xcv}$ race $\mathrm{T} 1 \mathrm{in}$ field resistance is not clear. Many plants expressing hypersensitivity to race T1 do not have high levels of resistance in the field, yet the most resistant plants all express hypersensitivity (Scott et al., unpublished data). In a race $\mathrm{T} 1$-infected backcross population, Wang (1992) found highly 
significant $(P<0.001)$ correlation coefficients of 0.39 and 0.41 between hypersensitivity and two field disease severity ratings. However, the moderate $r$ values indicated that all of the variation for field resistance was not accounted for by hypersensitive responses alone. Our study did not show unequivocally that race $\mathrm{T} 3$ hypersensitivity induced field resistance. The most resistant accessions in 1992 did not express hypersensitive reactions in the growth room, but the most resistant accessions in 1993 had hypersensitive responses. PI 126932 (unselected) was susceptible both years despite expressing hypersensitive reactions in the growth room. The same was true for PI 128216 when tested in 1993. Both these PIs were screened for rapid, confluent necrosis, and some of these selections (PI 126932-1-2, PI 128216-S) were more field resistant than their unselected counterparts. Thus, the speed of the necrotic reaction may be a factor in field resistance expression. Another important factor could be the genetic background in which the hypersensitivity occurs. The two $\mathrm{F}_{1} \mathrm{~s}$ with unselected PI 126932 were as resistant as PI 126932-1-2 in 1993 (Table 2). Perhaps the resistance of the hybrids was enhanced by background genes from Hawaii 7998 or PI 271385, which were intermediate (less disease than 'Solar Set' in 1 of 2 years) in race T3 resistance (Tables 1 and 2). However, the roles of rapid necrosis and genetic background require further elucidation. As mentioned above, the two $F_{1} s$ of PI 126932 expressed hypersensitivity, which indicates dominance for the hypersensitive response as opposed to the re- cessive nature of the hypersensitive response to race T1 (Wang et al., 1994).

The most encouraging result from this work was that Hawaii 7981 remained virtually disease-free when inoculated with race T3 in 1993. Hawaii 7981 also was highly resistant in 1994 field experiments (Scott et al., unpublished data). However, when Hawaii 7981 was tested for race T1 resistance in 1984 it was susceptible (Scott et al., unpublished data). Therefore, race $\mathrm{T} 3$ resistance needs to be incorporated into race $\mathrm{T} 1$ resistant lines to provide resistance to both races.

\section{Literature Cited}

Conover, R.A. and N.R. Gerhold. 1981. Mixtures of copper and maneb or mancozeb for control of bacterial spot of tomato and their compatibility for control of fungus diseases. Proc. Fla. State Hort. Soc. 94:154-156.

Cox, R.S. 1966. The role of bacterial spot on tomato production in south Florida. Plant Dis. Rptr. 50:699-700.

El-Morsy, G.A., G.C. Somodi, J.W. Scott, R.E. Stall, and J.B. Jones. 1994. Aggressiveness of Xanthomonas campestris pv. vesicatoria tomato race 3 (T3) strains over tomato race 1 (T1) strains: Evidence for antagonism. Phytopathology 84:1094. (Abstr.)

Horsfall, J.G. and R.W. Barratt. 1945. An improved system for measuring plant disease. Phytopathology 36:655. (Abstr.)

Jones, J.B. and J.W. Scott. 1986. Hypersensitive response in tomato to Xanthomonas campestris pv. vesicatoria. Plant Dis. 70:337-339.

Jones, J.B., R.E. Stall, J.W. Scott, G.C. Somodi, H. Bouzar, and N.C. Hodge. 1995. A third tomato race of Xanthomonas campestris pv. vesicatoria. Plant Dis. 79:395-398.

Nayudu, M.V. and J.C. Walker. 1960. Bacterial spot of tomato as influenced by temperature and by age and nutrition of the host. Phytopathology 50:360-364.

Pohronezny, K. and R.B. Volin. 1983. The effect of bacterial spot on yield and quality of freshmarket tomatoes. HortScience 18:69-70.

Scott, J.W. and J.B. Jones. 1986. Sources of resistance to bacterial spot [Xanthomonas campestris pv. vesicatoria (Doidge) Dye] in tomato. HortScience 21:304-306.

Scott, J.W. and J.B. Jones. 1989. Inheritance of resistance to foliar bacterial spot of tomato incited by Xanthomonas campestris pv. vesicatoria. J. Amer. Soc. Hort. Sci. 114:111-114.

Scott, J.W., J.B. Jones, and G. Cameron Somodi. 1989. Genetic resistance to bacterial spot in tomato. Proc. Tomato and Pepper Production in the Tropics. Asian Veg. Res. \& Dev. Ctr. Shanhua, Tainan, Taiwan. p. 200-207.

Somodi, G. Cameron, J.B. Jones, J.W. Scott, and J.P. Jones. 1994. Screening tomato seedlings for resistance to bacterial spot. HortScience 29:680 682.

Wang, J-F. 1992. Resistance to Xanthomonas campestris pv. vesicatoria in tomato. PhD Diss., Univ. of Florida, Gainesville.

Wang, J-F., J.B. Jones, J.W. Scott, and R.E. Stall 1994. Several genes in Lycopersicon esculentum control hypersensitivity to Xanthomonas campestris pv. vesicatoria. Phytopathology 84:702-706.

Whalen, M.C., J-F. Wang, F.M. Carland, M.E Heiskell, D. Dahlbeck, G.V. Minsavage, J.B. Jones, J.W. Scott, R.E. Stall, and B.J. Staskawicz. 1993. A virulence gene avrRxv from Xanthomonas campestris pv. vesicatoria specifies resistance on tomato line Hawaii 7998. Mol. Plant-Microbe Interact. 6:616-627. 